\title{
COVID-19 infection in a patient with multiple sclerosis treated with fingolimod
}

Mahdi Barzegar, MD, Omid Mirmosayyeb, MD, Nasim Nehzat, PharmD, Reza Sarrafi, MD, Farzin Khorvash, MD, Amir-Hadi Maghzi, MD, and Vahid Shaygannejad, MD

Neurol Neuroimmunol Neuroinflamm 2020;7:e753. doi:10.1212/NXI.0000000000000753

In December 2019, a novel coronavirus causing an infectious respiratory disease (COVID-19) was identified, which since then has developed into a pandemic with higher rates of mortality in older individuals and those with underlying medical conditions. ${ }^{1}$ Multiple sclerosis (MS) is an immune-mediated neurologic disease which requires long-term treatment with immunotherapies that have been shown to increase the risk of infections. ${ }^{2}$ As a result, there is significant anxiety among patients and neurologists during the pandemic regarding the infection outcome in this patient population. We present a patient with MS treated with fingolimod who was diagnosed with COVID-19 and had a favorable outcome.

\section{Case presentation}

A 42-year-old woman who was diagnosed with relapsing-remitting MS according to the McDonald criteria in 2001 and had been treated with methotrexate ( 2 years; discontinued because of elevated liver enzymes), interferon beta 1-a (13 years; discontinued because of disease activity), and recently on fingolimod (since 4 years ago) presented with muscle aches, gait difficulty, sensory disturbances, and weakness on the right side. Her other comorbidities included major depression disorder, hypothyroidism, recurrent urinary tract infection, and histories of pulmonary embolism on direct oral anticoagulation and myasthenia gravis (diagnosed 5 years before MS and status after thymectomy). At her most recent follow-up in September 2019, her expanded disability status scale (EDSS) score was 1.0 for a positive Babinski sign on the right side. MRI was notable for moderate disease burden in the brain and the presence of 2 right-sided cervical cord lesions. Her lymphocyte count at this visit was $842.4 / \mu \mathrm{L}$.

On March 1, 2020, she started experiencing the symptoms that gradually worsened over the next few days. She sought medical attention on March 5 and was seen at the outpatient MS clinic. Neurologic examination revealed decreased sensation, reduced muscle strength (4/5), and brisk reflexes on the right and right positive Babinski sign (EDSS of 4). These findings were consistent with new relapse or recrudescence of old symptoms (pseudoexacerbation). She was then admitted for a relapse workup and treatment on the same day. On arrival, she was afebrile with vital signs within normal limits. Initial laboratory investigations were notable for C-reactive protein of $76 \mathrm{mg} / \mathrm{L}$ and erythrocyte sedimentation rate of $46 \mathrm{~mm}$, raising suspicious for an underlying infectious etiology. There was also a decrease in absolute lymphocyte count $(601.6 / \mu \mathrm{L})$, which was attributed to fingolimod. Methylprednisolone IV 1,000 $\mathrm{mg} / \mathrm{d}$ was initiated for 3 days for the treatment of a possible relapse. As part of the infectious workup, chest X-ray showed a ground glass opacity (figure, A), which raised a possibility of community-acquired pneumonia for which she was started on azithromycin $500 \mathrm{mg}$ daily because she is allergic to fluoroquinolones. On March 7, she developed dry cough, dyspnea, and fever $\left(38.7^{\circ} \mathrm{C}\right)$. She also had tachycardia (122), increased respiratory rate (30), and slight decrease in blood pressure $(100 / 70 \mathrm{~mm} \mathrm{Hg})$ and in oxygen saturation $(89 \%)$ with a decrease

\author{
Correspondence \\ Dr. Shaygannejad \\ v.shaygannejad@gmail.com
}




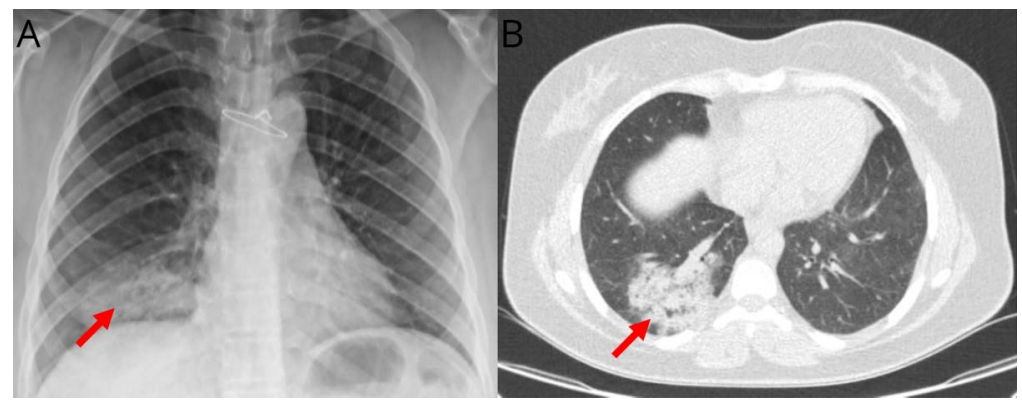

(A) Chest x-ray of the patient on the first day of hospitalization showing a ground glass opacity on the base of the right lung. (B) CT scan of the chest on the fourth day of hospitalization showing ground glass opacities/consolidation with crazy paving appearance highly suggestive for COVID-19.

in lymphocyte counts to $440.8 / \mu \mathrm{L}$. Fingolimod was stopped because of concern for sepsis. Ceftriaxone $1 \mathrm{~g}$ twice daily was added and started on oxygen via a nasal cannula. Chest CT was performed to rule out pulmonary embolism, given her history; however, it was indicative of ground glass opacities (figure, B). ${ }^{3}$ Given the clinical and imaging findings, COVID-19 was suspected, and a nasopharyngeal swab was obtained and sent to the Isfahan University of Medical Sciences reference laboratory for real-time PCR testing for COV. She was transferred to the special COVID ward and received a combination of hydroxychloroquine, oseltamivir (to cover for influenza), and piperacillin/tazobactam, whereas ceftriaxone and azithromycin were discontinued. Three days later (11th March), she felt well and vital signs were stabilized, and she became afebrile and the lymphocyte counts increased to 510.3/ $\mu \mathrm{L}$. On March 12, the COVID-19 test was reported positive, and all other medications except hydroxychloroquine were discontinued. The symptoms of cough and dyspnea together with neurologic symptoms gradually improved. She was discharged after a 13-day admission and started on glatiramer acetate to avoid potential MS rebound after the discontinuation of fingolimod (lymphocyte count: $1,000.5 / \mathrm{ul}$ ). Until the last televisit (30 March), she has been self-quarantined at home with no respiratory or neurologic symptoms. Given that she did not get a new MRI during the admission because of hemodynamic instability and also testing positive for COVID, it remains unclear whether her neurologic symptoms were because of the new disease activity (relapse) or worsening of preexisting symptoms (pseudorelapse).

\section{Discussion}

Because most patients with immune-mediated disorders such as MS are treated with immunosuppressive agents, it is hypothesized that this patient population is at a higher risk for developing severe COVID-19. Consensus statements mostly recommend cautious in the use and initiation of high-efficacy medications and deem the lower-efficacy medications safer during the pandemic. ${ }^{4}$ Therapeutic decision-making is more challenging in patients with active COVID-19 in whom discontinuation of immunotherapies could lead to rebound disease activity (e.g., fingolimod). ${ }^{5,6}$

In our patient, despite multiple comorbidities, the COVID-19 was resolved with good outcome, and there was no need for intensive care unit or intubation. Of note is that the initial presentation of COVID-19 was worsening of neurologic symptoms, which is commonly seen in patients with MS in context of infections. ${ }^{7}$ As a result, pseudoexacerbations or relapses without a clear etiology should prompt COVID-19 testing during the pandemic.

\section{Study funding}

No targeted funding reported.

\section{Disclosure}

M. Barzegar, O. Mirmosayyeb, N. Nehzat, R. Sarrafi, F. Khorvash, A.-H. Maghzi, V. Shaygannejad report no relevant disclosures. Go to Neurology.org/NN for full disclosures.

\section{Publication history}

Received by Neurology: Neuroimmunology \& Neuroinflammation April 2, 2020. Accepted in final form April 20, 2020.

\section{Appendix Authors}

\begin{tabular}{lll}
\hline Name & Location & Contribution \\
\hline Mahdi & Isfahan University of & $\begin{array}{l}\text { Acquired data, interpreted } \\
\text { data, and drafted the } \\
\text { marzegar, MD }\end{array}$ \\
Medical Sciences, Iran & $\begin{array}{l}\text { mancript for intellectual } \\
\text { content }\end{array}$
\end{tabular}

\begin{tabular}{lll}
\hline Omid & Isfahan University of & $\begin{array}{l}\text { Acquired data, interpreted } \\
\text { data, and revised the } \\
\text { Mirmosayyeb, }\end{array}$ \\
MD & Medical Sciences, Iran & $\begin{array}{l}\text { manuscript for intellectual } \\
\text { content }\end{array}$
\end{tabular}

Nasim Nehzat, Isfahan University of Interpreted data and PharmD Medical Sciences, Iran revised the manuscript for intellectual content 


\begin{tabular}{|c|c|c|}
\hline Name & Location & Contribution \\
\hline $\begin{array}{l}\text { Reza Sarrafi, } \\
\text { MD }\end{array}$ & $\begin{array}{l}\text { Isfahan University of } \\
\text { Medical Sciences, Iran }\end{array}$ & $\begin{array}{l}\text { Acquired data, interpreted } \\
\text { data, and revised the } \\
\text { manuscript for intellectual } \\
\text { content }\end{array}$ \\
\hline $\begin{array}{l}\text { Farzin } \\
\text { Korvash, MD }\end{array}$ & $\begin{array}{l}\text { Isfahan University of } \\
\text { Medical Sciences, Iran }\end{array}$ & $\begin{array}{l}\text { Acquired data, interpreted } \\
\text { data, and revised the } \\
\text { manuscript for intellectual } \\
\text { content }\end{array}$ \\
\hline $\begin{array}{l}\text { Amir-Hadi } \\
\text { Maghzi, MD }\end{array}$ & $\begin{array}{l}\text { Brigham and Women's } \\
\text { Hospital, Harvard } \\
\text { Medical School, Boston, } \\
\text { MA }\end{array}$ & $\begin{array}{l}\text { Interpreted data and } \\
\text { revised the manuscript for } \\
\text { intellectual content }\end{array}$ \\
\hline $\begin{array}{l}\text { Vahid } \\
\text { Shaygannejad, } \\
\text { MD }\end{array}$ & $\begin{array}{l}\text { Isfahan University of } \\
\text { Medical Sciences, Iran }\end{array}$ & $\begin{array}{l}\text { Interpreted data and } \\
\text { revised the manuscript for } \\
\text { intellectual content }\end{array}$ \\
\hline
\end{tabular}

\section{References}

1. Guan W, Ni Z, Hu Y, et al. Clinical characteristics of coronavirus disease 2019 in China. N Engl J Med Epub 2020 Feb 28.

2. Luna G, Alping P, Burman J, et al. Infection risks among patients with multiple sclerosis treated with fingolimod, natalizumab, rituximab, and injectable therapies. JAMA Neurol 2020;77:184-191.

3. Bernheim A, Mei X, Huang M, et al. Chest CT findings in coronavirus disease19 (COVID-19): relationship to duration of infection. Radiology Epub 2020 Feb 20.

4. Giovannoni G, Hawkes C, Lechner-Scott J, Levy M, Waubant E, Gold J. The COVID19 pandemic and the use of MS disease-modifying therapies. Mult Scler Relat Disord 2019;39:102073.

5. Barry B, Erwin AA, Stevens J, Tornatore C. Fingolimod rebound: a review of the clinical experience and management considerations. Neurol Ther 2019;8: 241-250.

6. Novi G, Ghezzi A, Pizzorno M, et al. Dramatic rebounds of MS during pregnancy following fingolimod withdrawal. Neurol Neuroimmunol Neuroinflamm 2017;4: e377. doi: 10.1212/NXI.0000000000000753.

7. Steelman AJ. Infection as an environmental trigger of multiple sclerosis disease exacerbation. Front Immunol 2015;6:520. 


\section{Neurology \\ Neuroimmunology \& Neuroinflammation}

\section{COVID-19 infection in a patient with multiple sclerosis treated with fingolimod Mahdi Barzegar, Omid Mirmosayyeb, Nasim Nehzat, et al. \\ Neurol Neuroimmunol Neuroinflamm 2020;7; DOI 10.1212/NXI.0000000000000753}

This information is current as of May 5, 2020

\section{Updated Information \& Services}

References

Citations

Subspecialty Collections

Permissions \& Licensing

Reprints including high resolution figures, can be found at: http://nn.neurology.org/content/7/4/e753.full.html

This article cites 5 articles, 1 of which you can access for free at: http://nn.neurology.org/content/7/4/e753.full.html\#\#ref-list-1

This article has been cited by 4 HighWire-hosted articles: http://nn.neurology.org/content/7/4/e753.full.html\#\#otherarticles

This article, along with others on similar topics, appears in the following collection(s):

COVID-19

http://nn.neurology.org//cgi/collection/covid_19

Multiple sclerosis

http://nn.neurology.org//cgi/collection/multiple_sclerosis

Information about reproducing this article in parts (figures,tables) or in its entirety can be found online at:

http://nn.neurology.org/misc/about.xhtml\#permissions

Information about ordering reprints can be found online: http://nn.neurology.org/misc/addir.xhtml\#reprintsus

Neurol Neuroimmunol Neuroinflamm is an official journal of the American Academy of Neurology.

Published since April 2014, it is an open-access, online-only, continuous publication journal. Copyright

Copyright (C) 2020 The Author(s). Published by Wolters Kluwer Health, Inc. on behalf of the American

Academy of Neurology.. All rights reserved. Online ISSN: 2332-7812.

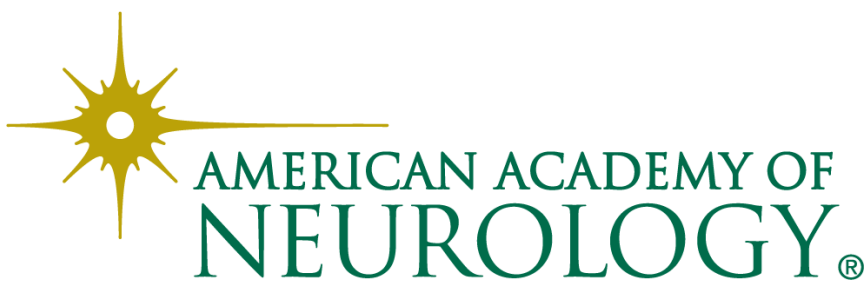

